\title{
PERAN SERTA MASYARAKAT DALAM MENSOSIALISASIKAN PONDOK PESANTREN DARUT TAFSIR
}

\begin{abstract}
Kholidatunur*
Abstract: This study attempts to examine and analyze in detail the role of the community in disseminating the Darut Tafsir Islamic Boarding School at the city of Bogor, West Java. For more details, this study examines in detail on "how to promote community participation in Darut Tafsir Islamic Boarding School?", Which focused on: 1) community participation in boarding school socialization planning, 2) community participation in boarding school socialization leading, 3) community participation in boarding school socialization controlling. This study will use a qualitative approach and methods used in this study is the case study method. It will be discussed in this study are: Firstly, community participation in socialization boarding school planning, consisting of: a) community participation in socialization planning, $b$ ) the way to involve the community participation in socialization planning, c) community participation in the process of socialization planning. Secondly, community participation in boarding school socialization leading, consisting of: a) community participation in socialization leading, b) the way to involve the community participation in socialization leading, c) community participation in the process of socialization leading. And thirdly, community participation in boarding school socialization controlling, consisting of: a) community participation in socialization controlling, b) the way to involve the community participation in socialization controlling, c) community participation in the process of socialization controlling.
\end{abstract}

Keywords: community participation, socialization, and boarding school

\section{PENDAHULUAN}

Pandangan sebagian masyarakat terhadap konsistensi atau kemerosotan sebuah pondok pesantren, selalu melekat kepada kiai sebagai figur pesantren. Misalnya, dengan meninggalnya kiai, sebuah pondok pesantren akan mengalami kemerosotan atau bahkan lenyap. Seperti yang telah disebutkan dalam harian Republika Dialog Jum'at (hari Jum'at tanggal 7 Oktober 2011): "Di Pesantren terdapat guru utama yang dikenal dengan sebutan kiai. Para kiai inilah yang memainkan peranan penting dalam perkembangan dunia pesantren di Indonesia. Biasanya, pesantren mengalami kemunduran bila kiainya wafat".

Akan tetapi, selain peran kiai yang menjadi figur penting dalam sebuah pondok pesantren, peran serta masyarakat (terutama alumni) juga tidak bisa lepas dari pengelolaan sebuah lembaga pendidikan, terutama pada otonomi daerah saat ini. Meski sebelum kebijakan otonomi daerah diterapkan, pondok pesantren sudah melaksanakan kebijakan pendidikannya secara mandiri, termasuk melibatkan masyarakat dalam pengelolaan pendidikan.

Pondok Pesantren Darut Tafsir merupakan lembaga pendidikan Islam yang masih berdiri setelah pergantian kepemimpinannya. Pondok Pesantren Darut Tafsir

\footnotetext{
* Staf pengajar di Pondok Pesantren Darut Tafsir, Bogor
} 
mengalami perubahan struktural setelah wafatnya pemimpin pertama sekaligus pendiri Pondok Pesantren Darut Tafsir. Meski terkadang mengalami peningkatan dan penurunan dalam penerimaan santri/ siswa baru pada tiap tahunnya, pondok pesantren ini masih tetap bertahan. Dibalik hadirnya santri di pondok pesantren tersebut, terdapat peran serta masyarakat (alumni) yang membantu mensosialisasikan Pondok Pesantren Darut Tafsir.

Fokus yang diangkat adalah mengenai peran serta masyarakat yakni alumni dalam mensosialisasikan pondok pesantren. Hal tersebut diangkat menjadi fokus karena menjadi keunikan bagi Pondok Pesantren Darut Tafsir. Dengan keterlibatan alumni secara langsung dalam kegiatan-kegiatan di Pondok Pesantren Darut Tafsir, tidak menjadikan terputusnya hubungan antara lembaga pendidikan tersebut dengan masyarakat terutama alumni. Pentingnya kerjasama antara pihak pondok pesantren dengan masyarakat terutama alumni adalah untuk saling memberikan pengertian dan kepercayaan, menambah erat persaudaraan antara Pondok Pesantren Darut Tafsir dengan masyarakat, mensosialisasikan program Pondok Pesantren Darut Tafsir yang berlangsung maupun yang akan datang, dan agar Pondok Pesantren Darut Tafsir tetap bertahan dan semakin maju.

\section{Pondok Pesantren}

Abd. Muin M (2007:17-18) memaparkan pengertian pesantren yaitu: Pesantren merupakan lembaga pendidikan dengan bentuk khas sebagai tempat di mana proses pengembangan keilmuan, moral dan ketrampilan para santri menjadi tujuan utamanya. Istilah pesantren berasal dari kata santri dengan awalan "pe" dan akhiran "an" yang berarti tempat tinggal santri. Kata santri sendiri menurut John berasal dari Bahasa Tamil yang berarti guru mengaji. Sedangkan menurut Berg berasal dari kata shastri yang dalam bahasa India berarti orang yang tahu buku-buku suci agama Hindu atau sarjana ahli kitab agama Hindu. Sebagai lembaga pendidikan Islam, pesantren memiliki lima elemen penting yaitu pondok tempat menginap santri, masjid, santri, pengajaran kitabkitab klasik, dan kyai.

Menurut M. Arifin (2007:2) pondok pesantren adalah suatu lembaga pendidikan agama Islam yang tumbuh serta diakui masyarakat sekitar, dengan sistem asrama (komplek) di mana santri-santri menerima pendidikan agama melalui sistem pengajian atau madrasah yang sepenuhnya berada di bawah kedaulatan dari leadership seorang atau beberapa orang kiai dengan ciri-ciri khas yang bersifat karismatik serta independen dalam segala hal. Sedangkan menurut Mastuhu (1994:55), pesantren adalah "lembaga pendidikan tradisional Islam untuk mempelajari, memahami, mendalami, menghayati, dan mengamalkan ajaran Islam dengan menekankan pentingnya moral keagamaan sebagai pedoman perilaku sehari-hari.

Berdasarkan deskripsi konsep di atas dapat disintesiskan, pondok pesantren berarti suatu lembaga pendidikan Islam yang di dalamnya terdapat santri, kiai, masjid, tempat belajar agama, kurikulum agama, dan tempat tinggal santri dan yang di dalamnya terdapat proses pendidikan keagamaan (Islam) dan jenis pendidikan lainnya, di bawah leadership seorang atau beberapa orang kiai yang bersifat karismatik serta independen dan mandiri. 


\section{Peran Serta Masyarakat}

Peran serta masyarakat menurut Danny Burns, et.al. (2004:2) adalah: Community participation concerns engagement of individuals and communities in decisions about things that affect their lives... Community participation means that communities are playing an active part and have a significant degree of power and influence. Peran serta masyarakat menyangkut keterlibatan individu dan masyarakat dalam pengambilan keputusan tentang hal-hal yang mempengaruhi kehidupan mereka. Menurut Becker dalam Henry Sanoff (2000:8), peran serta masyarakat adalah: (Participation) reduces the feeling of anonymity and communicates to the user a greater degree of concern on the part of the management of administration. (with) it, residents are actively involved in the development process, there will be a better maintained phsycal environment, greater public spirit, more user satisfaction and significant financial changes. Peran serta dapat melibatkan warga secara aktif dalam proses pembangunan, semangat masyarakat lebih besar, kepuasan pengguna yang lebih dan perubahan keuangan yang signifikan.

Dapat disintesiskan, peran serta masyarakat adalah pelibatan masyarakat dalam pembuatan atau pengambilan keputusan suatu kegiatan dalam proses pembangunan yang dapat mempengaruhi kehidupan mereka. Bentuk peran serta/ partisipasi masyarakat adalah: a) Finansial, b) Proteksi, c) moral, d) akademis, e) kurikulum, f) sumber belajar, g) IT (Ilmu Teknologi, h) Kelembagaan, Manajerial, kepemimpinan.

\section{Sosialisasi}

Menurut Colquitt dkk (2011:569) mendefinisikan sosialisasi, "socialization is the primary process by which employess learn the social knowledge that enables them to understand and adapt to the organization's culture. It's a process that begins before an employee starts work and doesn't end until an employee leaves the organization. Sosialisasi merupakan proses seseorang untuk mempelajari pengetahuan sosial yang memungkinkannya untuk memahami dan beradaptasi dengan budaya organisasi di organisasi seseorang tersebut bernaung. Menurut Gibson dkk (2006:215), "socialization is the process by which the individual learns and internalizes the values, expected behaviors, and social knowledge that are important for becoming an effective organizational member". Sosialisasi adalah proses dimana individu belajar dan menginternalisasi nilai-nilai, perilaku yang diharapkan, dan pengetahuan sosial yang penting untuk menjadi anggota organisasi yang efektif. Dengan demikian, dapat disintesiskan bahwa sosialisasi merupakan suatu proses seseorang yang mempelajari kehidupan sosial suatu tempat/ organisasi dan memperoleh pengetahuan, keterampilan dan membentuk suatu perilaku agar dapat diterima masyarakat dalam tempat masyarakat tersebut bernaung. 


\section{METODE}

Penelitian ini dilaksanakan di Pondok Pesantren Darut Tafsir, desa Cibanteng Pabuaran Kecamatan Ciampea Kabupaten Bogor, Jawa Barat, dengan pertimbangan bahwa pondok pesantren tersebut setelah pergantian kiai dan melibatkan peran serta masyarakat, tetap berdiri. Penelitian ini menggunakan pendekatan kualitatif dan metode yang digunakan dalam penelitian adalah metode studi kasus. Analisis data dilakukan selama pengumpulan data dan setelah data terkumpul. Kemudian dilakukan pemeriksaan keabsahan data dengan kredibilitas, signifikan, dan komprehensif/konfirmabilitas.

\section{HASIL DAN PEMBAHASAN}

\section{Peran Serta Masyarakat dalam Perencanaan Sosialisasi Pondok Pesantren}

\section{Bentuk Peran Serta Masyarakat dalam Perencanaan Sosialisasi}

Adanya peran serta masyarakat dalam perencanaan sosialisasi ditandai dengan keterlibatan masyarakat/ alumni dalam bentuk ilmu teknologi, moral, akademis dan manajerial. Bentuk peran serta masyarakat dalam perencanaan sosialisasi tersebut berupa: 1) menyediakan alat-alat yang diperlukan untuk membuat profil maupun website seperti: kamera video, kamera, laptop (IT); 2) menyediakan tempat (rumah/ majlis) untuk kegiatan sosialisasi; 3) bersikap ta'zhim dan ikhlas kepada guru, memiliki kemauan untuk turut membantu dan bekerjasama dalam mensosialisasikan pondok pesantren; 4) turut menetapkan tujuan dalam kegiatan sosialisasi yakni bertambahnya jumlah santri dan eksistensi pondok pesantren; 5) menyumbangkan ide berupa program pembuatan profil pondok dalam bentuk visualisasi dengan mengadakan syuting kegiatan pengurus pondok pesantren dan santri di Pondok Pesantren Darut Tafsir; 6) menyediakan alat transportasi.

\section{Cara Melibatkan Masyarakat dalam Perencanaan Sosialisasi}

Adanya kerjasama dan ajakan dari pihak pondok pesantren kepada masyarakat/ alumni dalam perencanaan sosialisasi ditandai dengan: 1) memberikan kepercayaan kepada alumni untuk turut serta dalam perencanaan sosialisasi; 2) memberikan informasi kepada ketua pengurus alumni mengenai sosialisasi pondok pesantren; 3) memberikan tugas kepada alumni dalam kegiatan tertentu, termasuk mensosialisasikan pondok pesantren agar timbul rasa tanggung jawab dalam diri alumni sehingga turut serta dalam setiap kegiatan Pondok Pesantren Darut Tafsir; 4) membuat program kerja yakni pembinaan terhadap alumni, 5) saling membantu dan bekerja sama dalam perencanaan dan pelaksanaan program masing-masing.

\section{Peran Serta Masyarakat dalam Proses Perencanaan Sosialisasi}

Proses perencanaan sosialisasi dilakukan secara bertahap dimulai dari 1) menetapkan tujuan, yakni bertambahnya jumlah santri/ siswa atau lebih kepada eksistensi pondok pesantren; 2) menetapkan strategi yang akan dilakukan untuk mencapai tujuan, seperti: kunjungan ke daerah-daerah alumni, PPL/ PDL, menyebarkan brosur, mempertahankan kepercayaan masyarakat; 3) memilih orangorang yang akan melaksanakan tugas, berkelompok maupun perorangan; 4) 
menjadwalkan kegiatan, menetapkan biaya yang diperlukan, menetapkan tempat kegiatan, dan 5) evaluasi. Meski melibatkan seluruh komponen pondok pesantren, akan tetapi peran pimpinan umum lebih dominan dalam menentukan arah dan pelaksanaan kegiatan.

\section{Peran Serta Masyarakat dalam Penggerakkan Sosialisasi Pondok Pesantren}

\section{Bentuk Peran Serta Masyarakat dalam Penggerakkan Sosialisasi}

Adanya peran serta masyarakat dalam penggerakkan sosialisasi ditandai dengan keterlibatan masyarakat/ alumni dalam bentuk ilmu teknologi, moral, dan manajerial. Bentuk peran serta masyarakat dalam penggerakkan sosialisasi tersebut berupa: 1) menyediakan alat-alat yang diperlukan untuk berkomunikasi seperti: HP, laptop, modem, dan lain-lain; 2) menyediakan tempat (rumah/ majlis) untuk kegiatan sosialisasi; 3) bersikap ta'zhim dan ikhlas kepada guru, memiliki kemauan untuk turut membantu dan bekerjasama dalam mensosialisasikan pondok pesantren; 4) mengkoordinasikan kepada masyarakat/ alumni lainnya tentang pelaksanaan sosialisasi.

Pendapat Gibson (2006:204), "participation refers to the extent that a person's knowledge, opinions, and ideas are included in the decision making process. it is an important part of working in organizations for some people". Peran serta/ partisipasi mengacu pada pengetahuan, pendapat, ide-ide seseorang yang termasuk dalam pengambilan keputusan adalah merupakan bagian yang penting dalam perkerjaan di organisasi.

\section{Cara Melibatkan Masyarakat dalam Penggerakkan Sosialisasi}

Adanya kerjasama dan ajakan dari pihak pondok pesantren kepada masyarakat/ alumni dalam penggerakkan sosialisasi ditandai dengan Pondok Pesantren Darut Tafsir: 1) memberikan tugas kepada masyarakat/ alumni dalam penggerakkan sosialisasi; 2) memberikan pengarahan; 3) memberikan motivasi agar melaksanakan tugas dengan sungguh-sungguh dan berhasil; 4) melibatkan masyarakat/ alumni; 5) berkomunikasi yang baik antara pimpinan umum, petugas sosialisasi, alumni; 6) melakukan pembinaan kepada alumni; 7) saling membantu, mengajak diskusi, dan 8) saling percaya dalam penggerakkan sosialisasi.

\section{Peran Serta Masyarakat dalam Proses Penggerakkan Sosialisasi}

Dalam proses penggerakkan sosialisasi, pondok pesantren melibatkan masyarakat/ alumni. Hal tersebut dibuktikan dengan hasil penelitian bahwa Pondok Pesantren Darut Tafsir: 1) memberikan informasi kepada masyarakat/ alumni bahwa pondok sedang melaksanakan sosialisasi; 2) mengkomunikasikan tujuan sosialisasi kepada setiap elemen yang ada di pondok pesantren termasuk kepada masyarakat/ alumni; 3) memberikan petunjuk dan perintah mengenai tugas yang harus dilakukan, 4) mempengaruhi para staf dengan komunikasi yang baik dan uswatun hasanah agar mau melaksanakan tugas dengan baik; 5) memotivasi staf, masyarakat/ alumni; 6) meminta bantuan kepada tokoh masyarakat/ alumni agar turut mensosialisasikan program pondok pesantren kepada masyarakat lainnya. 
Robbins (2003:4) menyatakan "the planning function encompasses defining an organization's goals, establishing an overall strategy for achieving those goals, and developing a comprehensive hierarchy of plans to integrate and coordinate activities". Perencanaan meliputi menentukan tujuan organisasi, menetapkan strategi keseluruhan untuk mencapai tujuan tersebut dan mengembangkan rencana secara keseluruhan untuk mengintegrasikan dan mengkoordinasikan kegiatan suatu organisasi. 


\section{Peran Serta Masyarakat dalam Pengawasan Sosialisasi Pondok Pesantren}

\section{Bentuk Peran Serta Masyarakat dalam Pengawasan Sosialisasi}

Pengawasan sosialisasi Pondok Pesantren Darut Tafsir melibatkan masyarakat/ alumni dalam bentuk ilmu teknologi, moral, dan manajerial. Hal tersebut dibuktikan dengan hasil penelitian bahwa Pondok Pesantren Darut Tafsir: 1) melibatkan masyarakat/ alumni dalam pengawasan sosialisasi; 2) masyarakat membantu dan bekerja sama pondok pesantren dalam pengawasan sosialisasi; 3) adanya informasi yang disampaikan masyarakat/ alumni kepada pihak pondok pesantren mengenai pelaksanaan sosialisasi di tempat berlangsungnya kegiatan sosialisasi; 4) memanfaatkan teknologi seperti HP, internet, latop, dan modem; 5) adanya koordinasi antara pihak pondok dengan masyarakat/ alumni, pihak masyarakat/ alumni kepada masyarakat/ alumni lainnya.

\section{Cara Melibatkan Masyarakat dalam Pengawasan Sosialisasi}

Pondok Pesantren Darut Tafsir mengajak serta/ bekerja sama dengan masyarakat/ alumni dalam pengawasan sosialisasi pondok pesantren. Hal tersebut dibuktikan dengan hasil penelitian, bahwa Pondok Pesantren Darut Tafsir: 1) saling bertukar informasi dengan masyarakat alumni mengenai kelebihan dan kekurang pelaksanaan sosialisasi; 2) adanya laporan baik secara tertulis maupun tidak tertulis dari masyarakat/ alumni; 3) adanya kerja sama antara pondok pesantren dengan masyarakat/ alumni mengenai pengawasan pelaksanaan sosialisasi.

\section{Peran Serta Masyarakat dalam Proses Pengawasan Sosialisasi}

Proses pengawasan sosialisasi pondok pesantren melibatkan masyarakat/ alumni. Hal tersebut dibuktikan dengan adanya: 1) penetapan standar, yakni penetapan jumlah santri baru setelah kegiatan sosialisasi; 2) waktu pelaksanaan, laporan tertulis/ lisan, dan yang terlibat dalam kegiatan sosialisasi; 3) pengamatan oleh pimpinan umum pondok pesantren maupun masyarakat/ alumni, laporan-laporan baik lisan maupun tulisan; 4) membandingkan pelaksanaan nyata dengan pelaksanaan yang direncanakan; 5) adanya pengkorekasian yang dilakukan oleh masyarakat/ alumni. 


\section{PENUTUP}

\section{Kesimpulan.}

1. Peran serta masyarakat dalam perencanaan sosialisasi pondok pesantren dapat dilihat dari kesimpulan berikut: a) perencanaan sosialisasi Pondok Pesantren Darut Tafsir melibatkan masyarakat dalam bentuk ilmu teknologi, moral, akademis dan manajerial; b) Pondok Pesantren Darut Tafsir mengajak serta/ bekerjasama dengan masyarakat/ alumni dalam perencanaan sosialisasi pondok pesantren. Meski memberikan kesempatan kepada masyarakat/ alumni dalam mengemukakan ide/ gagasan, peran pimpinan umum lebih dominan dalam menentukan arah dan pelaksanaan kegiatan; c) proses perencanaan dilakukan secara bertahap dimulai dari menetapkan tujuan, menetapkan strategi yang akan dilakukan untuk mencapai tujuan, memilih orang-orang yang akan melaksanakan tugas, menjadwalkan kegiatan, menetapkan biaya yang diperlukan, menetapkan tempat kegiatan, dan evaluasi.

2. Peran serta masyarakat dalam penggerakkan sosialisasi pondok pesantren dapat dilihat dari kesimpulan berikut: a) Penggerakkan sosialisasi Pondok Pesantren Darut Tafsir melibatkan masyarakat dalam bentuk ilmu teknologi, moral, dan manajerial, b) Pondok Pesantren Darut Tafsir mengajak serta/ bekerja sama dengan masyarakat/ alumni dalam penggerakkan sosialisasi pondok pesantren dengan bentuk komunikasi, motivasi, pembinaan dan pengarahan, c) proses penggerakkan sosialisasi pondok pesantren melibatkan masyarakat/ alumni dengan usaha yang dilakukan pimpinan umum melalui orientasi, pemotivasian, kepemimpinan dan komunikasi.

3. Peran serta masyarakat dalam pengawasan sosialisasi pondok pesantren dapat dilihat dari kesimpulan berikut: a) pengawasan sosialisasi Pondok Pesantren Darut Tafsir melibatkan masyarakat dalam bentuk ilmu teknologi, moral, dan manajerial; b) Pondok Pesantren Darut Tafsir mengajak serta/ bekerjasama dengan masyarakat/ alumni dalam pengawasan sosialisasi pondok pesantren. Cara melibatkan peran serta masyarakat/ alumni dalam pengawasan tersebut berupa saling memberikan informasi antara pihak pondok pesantren dengan alumni; c) proses pengawasan sosialisasi pondok pesantren melibatkan masyarakat/ alumni. Dan pengawasan dilakukan dengan sistematis yang dimulai dari penetapan standar, penentuan pengukuran pelaksanaan kegiatan, pengukuran pelaksanaan kegiatan nyata, pembandingan pelaksanaan dengan standar dan penganalisaan penyimpanganpenyimpangan, dan pengambilan tindakan koreksi.

\section{Saran.}

1. Pada tahap perencanaan, pimpinan umum harus mengurangi dominasi dan dapat memberikan kesempatan kepada rekan kerja maupun masyarakat/ alumni untuk mengemukakan pendapat agar aktif;

2. Pada tahap penggerakkan, pimpinan umum harus memperjelas peran masingmasing pengurus pondok pesantren, dewan guru, petugas sosialisasi maupun alumni secara tertulis agar memudahkan informasi mengenai tugas yang harus dilaksanakan; 
3. Pada tahap pengawasan, penetapan standar, penentuan pengukuran pelaksanaan kegiatan, pengukuran pelaksanaan kegiatan nyata, pembandingan pelaksanaan dengan standar dan penganalisaan penyimpangan-penyimpangan, dan pengambilan tindakan koreksi harus dituliskan secara jelas untuk memudahkan informasi kepada pengurus pondok pesantren, dewan guru, dan alumni;

4. Angket harus dibuat oleh pimpinan umum/ pihak pondok pesantren maupun alumni untuk mengetahui tanggapan masyarakat mengenai pelayanan pendidikan di Pondok Pesantren Darut Tafsir;

5. Masyarakat/ alumni harus disertakan dalam kegiatan pondok pesantren karena akan terciptanya kerjasama yang baik dan jalinan silaturrahmi tidak terputus;

6. Perlu dilakukan penelitian lebih lanjut yang berkenaan dengan peran serta masyarakat dalam mensosialisasikan pondok pesantren dengan fokus yang lebih beragam. 


\section{DAFTAR RUJUKAN}

Burns, Danny, et al. Making Community Participation Meaningful. Great Britain: The Policy Press, 2004.

Handoko, T. Hani. Manajemen, Yogyakarta: BPFE-YOGYAKARTA, 2003.

Harian Republika: Dialog Jum'at, Ensiklopedi: Madrasah, hari Jum’at tanggal 7 Oktober 2011.

Mastuhu. Dinamika Sistem Pendidikan Pesantren: Suatu Kajian Tentang Unsur dan Nilai Sistem Pendidikan Pesantren, Jakarta: INIS, 1994.

Muin M, Abd., dkk. Pengembangan Ekonomi Pondok Pesantren. Jakarta: CV. Prasasti, 2007.

Qomar, Mujamil. Pesantren Dari Transformasi Metodologi Menuju Demokratisasi Institusi. Jakarta: Penerbit Erlangga, 2007.

Sanoff, Henry. Community Participation; Methods in Design and Planning. Canada: John Wiley\&Sons, Inc, 2000.

Colquitt, et al. Organizational Behavior: Improving Performance and Commitment the Workplace, New York: McGraw-Hill, 2011.

Gibson, dkk. Organization: behavior structure processes, New York: Mc-Graw Hill, 2006.

Robbins, Stephen P. Organizational Behavior, Saddle River, New Jersey: Pearson Education, 2003.

Siswanto, H.B. Pengantar Manajemen, Jakarta: Bumi Aksara, 2008.

Schermerhorn, John R. Introduction to Management, Hoboken: John Wiley \& Sons, 2010. 